\title{
Seasonal Variation in Nitrogen Accumulation of Soybean Plant as Affected by Combined Nitrogen and Light Intensity
}

\author{
Raafat K. Risit: \\ Faculty of Agriculture, Suez Canal Universitv, Ismailia \\ 41522, Egvpt
}

Received September 25, 1984

Nodulated soybean plant can assimilate combined nitrogen forms such as nitrate or ammonium nitrogen in addition to its capability to fix atmospheric nitrogen ${ }^{4,7,10)}$. It is also repeatedly reported that combined nitrogen considerably increases the nitrogen content in soybeans ${ }^{3,4,6,16)}$, which could reflect itself in a detectable increase in protein content of seeds ${ }^{12)}$. It was found that the nitrogen accumulation in whole plant followed a sigmoid pattern with plant development, while in pods, it increased linearly ${ }^{8)}$.

Combined nitrogen seemed to be able to replace biologically fixed nitrogen in the nitrogen nutrition of soybeans. In this regard, WERBER ${ }^{15)}$ reported that nodulating and nonnodulating isolines of soybeans could produce equal nitrogen content when adequate combined nitrogen was available.

Active uptake of nitrogen as well as nitrogen fixation by soybean plant needs a considerable amount of energy. In this respect, Minchis and $P_{\text {ATY }}{ }^{51}$ found that the respiratory efficiency for nitrate assimilation by roots was very similar to that for nitrogen fixation by nodules. This seems to be in harmony with the results obtained by Al.tison et $a^{11}$ who found that young roots respire at near the same rate per unit dry weight as young active nodules maintained in air.

Concerning the shading effect, it was reported that, soybean plants grown with no shade produced high nitrogen content than when plants were shaded ${ }^{11)}$, and although the seed protein percent was unaffected by shading variation ranging between $20 \%$ up to $80 \%$ shade, the total protein content in seeds was decreased as shade increased ${ }^{13}$.

The present work was conducted with shaded and unshaded soybean plants treated with combined nitrogen, Rhizobia, or combined nitrogen and Rhizobia, in order to investigate a) the seasonal variation in nitrogen accumulation of different plant parts, b) the relationship between respiratory activity of root system and nitrogen accumulation by plant and c) the efficiency of pod protein production at filling stage of growth, as a function of yield quality.

Table 1. Composition of the nutrient solution*

\begin{tabular}{|c|c|c|c|}
\hline \multicolumn{4}{|c|}{ Macronutrients } \\
\hline \multicolumn{2}{|c|}{$\begin{array}{l}\mathrm{N} \text { free nutrient } \\
\text { solution }\end{array}$} & \multicolumn{2}{|c|}{$\begin{array}{l}\text { Nutrient solution } \\
\text { contained } \mathrm{N}\end{array}$} \\
\hline Compound & $\mathrm{g} / \mathrm{l}$ & Compound & $\mathrm{g} / \mathrm{l}$ \\
\hline $\mathrm{K}_{2} \mathrm{SO}_{4}$ & $\begin{array}{l}1.164^{* *} \\
1.904^{* * *}\end{array}$ & $\mathrm{KNO}_{3}$ & $\begin{array}{l}0.289^{* *} \\
1.190^{* * *}\end{array}$ \\
\hline $\mathrm{MgSO}_{4}-7 \mathrm{H}_{2} \mathrm{O}$ & 0.246 & $\mathrm{~K}_{2} \mathrm{SO}_{4}$ & 0.880 \\
\hline $\mathrm{CaSO}_{4}-2 \mathrm{H}_{2} \mathrm{O}$ & 0.430 & $\mathrm{MgSO}_{4}-7 \mathrm{H}_{2} \mathrm{O}$ & 0.246 \\
\hline $\begin{array}{l}\mathrm{NaH}_{2} \mathrm{PO}_{4} \\
-2 \mathrm{H}_{2} \mathrm{O}\end{array}$ & 0.124 & $\mathrm{CaSO}_{4}-2 \mathrm{H}_{2} \mathrm{O}$ & 0.430 \\
\hline \multirow[t]{2}{*}{$\mathrm{Na}_{2} \mathrm{HPO}_{4}$} & \multirow[t]{2}{*}{0.170} & \multicolumn{2}{|c|}{$\mathrm{NaH}_{2} \mathrm{PO}_{4}-2 \mathrm{H}_{2} \mathrm{O} \quad 0.124$} \\
\hline & & $\mathrm{Na}_{2} \mathrm{HPO}_{4}$ & 0.170 \\
\hline \multicolumn{4}{|c|}{ Micronutrients } \\
\hline Compound & $\mathrm{mg} / \mathrm{l}$ & Compound & $\mathrm{mg} / \mathrm{l}$ \\
\hline $\mathrm{KCl}$ & 3.730 & $\mathrm{Na}_{2} \mathrm{MoO}_{4}-2 \mathrm{H}_{2} \mathrm{O}$ & 0.121 \\
\hline $\mathrm{H}_{3} \mathrm{BO}_{3}$ & 1.550 & $\mathrm{ZnSO}_{4}-7 \mathrm{H}_{2} \mathrm{O}$ & 0.580 \\
\hline $\mathrm{MnSO}_{4}-4 \mathrm{H}_{2} \mathrm{O}$ & 0.446 & Ethylene diamine & e tetra \\
\hline $\mathrm{CuSO}_{4}$ & 0.083 & $\begin{array}{l}\text { acetic acid mono } \\
\text { ferric salt }\end{array}$ & $\begin{array}{l}\text { sodium } \\
7.700\end{array}$ \\
\hline \multicolumn{4}{|c|}{ Beneficial element (Co) } \\
\hline Compound & $\mathrm{mg} / \mathrm{l}$ & & \\
\hline $\mathrm{CoCl}_{2}-6 \mathrm{H}_{2} \mathrm{O}$ & 0.220 & & \\
\hline
\end{tabular}

* Plants were irrigated with the nutrient solution $1 \sim 2$ times weekly up to $75 \%$ of water holding capacity.

** Used until three weeks after sowing.

*** Used from three weeks after sowing until maturity. 


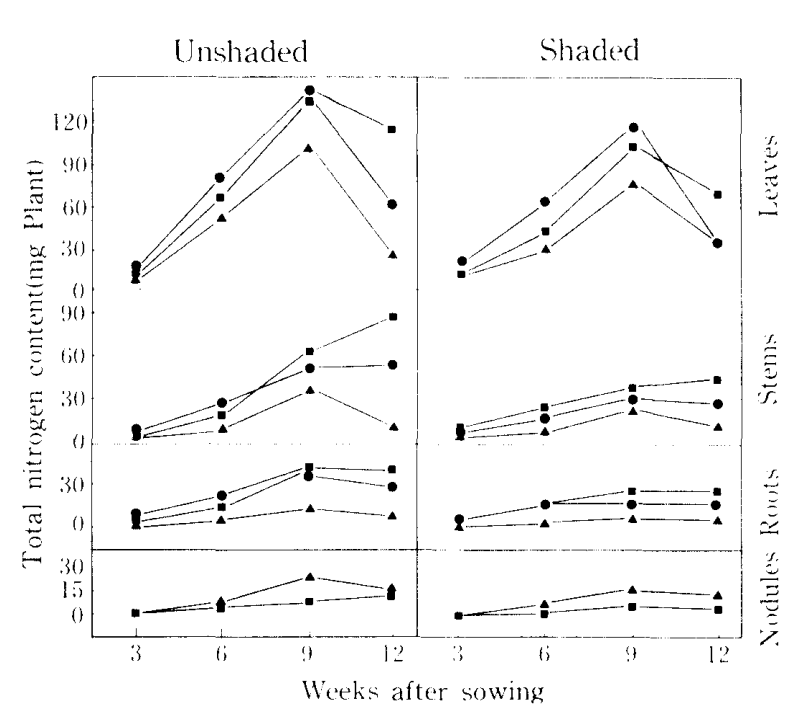

Fig. 1. Seasonal variation in total nitrogen accumulation in leaves, stems, roots and nodules of shaded and unshaded soybean plants as treated with combined nitrogen, Rhizobia or combined nitrogen and Rhizobia.

- : Plants grown with combined nitrogen (N).

A : Plants grown with Rhizobia ( R).

- : Plants grown with combined nitrogen and Rhizobia $(\mathrm{N}+\mathrm{R})$.

\section{Materials and Methods}

A pot experiment was carried out in a controlled growth chamber $\left(25^{\circ} \mathrm{C}\right.$ day $/ 20^{\circ} \mathrm{C}$ night), in which three groups of soybeans "kitamusume" were grown; a) plants were supplied with combined nitrogen without seed inoculation with Rhizobia (N), b) plants were not supplied with combined nitrogen but seeds were inoculafed with Rhizobia ( $R$ ), and c) plants were supplied with combined nitrogen and seeds were inoculated with Rhizobia* $(\mathrm{N}+\mathrm{R})$.

The plants were grown in vermiculite under full sunlight (unshaded plants) or continuous $50 \%$ shade (shaded plants), using one liter pots at a rate of one plant per pot, after RABIF and KuмAzıн: ${ }^{9)}$. Combined nitrogen as potassium nitrate was applied successively, as a component of nutrient solution (Table 1), to both $\mathrm{N}$-plants and $(\mathrm{N}+\mathrm{R})$ plants. The total amount of applied combined nitrogen was 500 mg $\mathrm{N}$ per pot throughout the growth season up to harvesting. In order to equalize the amount of supplied potassium in all

* Rhizobium japonicum strain (J-5033/NIAS).

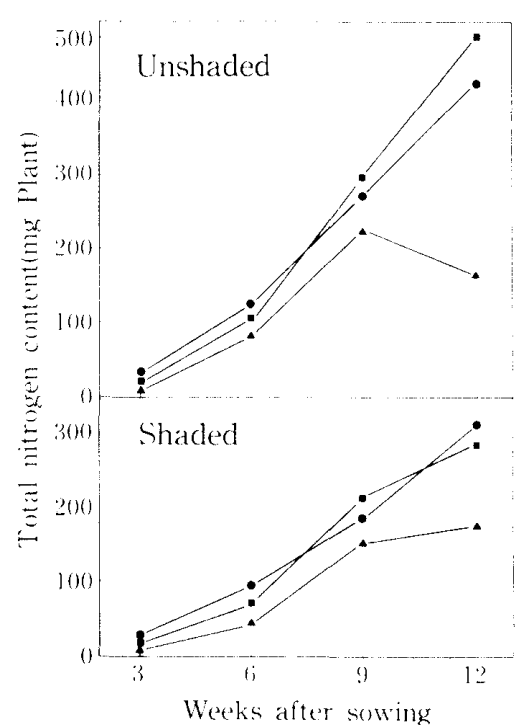

Fig. 2. Seasonal variation in total nitrogen accumulation of whole shaded and unshaded soybean plant as treated with combined nitrogen, Rhizobia or combined nitrogen and Rhizobia.

-: Plants grown with combined nitrogen $(\mathrm{N})$.

A : Plants grown with Rhizobia (R).

- : Plants grown with combined nitrogen and Rhizobia $(\mathrm{N}+\mathrm{R})$.

treatments, R-plants were supplied with additional dose of potassium sulfate. Three replicates were used with all treatments, except at pod filling, at which two replicates were harvested.

Root systems were excised for measurement of $\mathrm{CO}_{2}$ release of roots using a gas chromatograph equipped with TCD and a column containing Porapak $Q$ at $30^{\circ} \mathrm{C}^{9)}$.

Plants were sampled four times namely at vegetative, initial flowering, initial pod filling (I.P.F.), and pod filling (P.F.) stages of plant growth, nearly corresponding to $3,6,9,12$ weeks after sowing. Sampled plants were separated to different parts viz, leaves, stems, roots, nodules and (pods). Plant samples were oven dried at $70^{\circ} \mathrm{C}$ for $72 \mathrm{hr}$, ground and subjected to determination of total nitrogen by Kjeldahl method according to Association of Official Analytical Chemists ${ }^{2}$.

\section{Results and Discussion}

\section{Nitrogen accumulation}

Data illustrated in Fig. 1 show that, during the growth season, R-plants accumulated consistently low nitrogen content in leaves, stems and roots as compared with $(\mathrm{N})$ and 
$(\mathrm{N}+\mathrm{R})$ plants, and this was true under both shaded and unshaded conditions. The same trend proved to be true with concern to the whole plant as indicated in Fig. 2. These results conclude that the utilization of biologically fixed nitrogen as a sole nitrogen source for soybean plant is not adequate because of its high requirements of nitrogen element, and the application of combined nitrogen seems to be significant, particularly in soils with low nitrogen content. The above results also confirm that combined nitrogen can entirely replace the fixed nitrogen in the nitrogen nutrition of soybeans.

At pod filling stage, under both shaded and unshaded coditions, $(\mathrm{N}+\mathrm{R})$ plants accumulated high nitrogen content in leaves, stems and roots as compared to N-plants (Fig. 1 ), and this was reflected in same trend with whole plant particularly under unshaded conditions (Fig. 2). This revealed that, even under adequate supply of combined nitrogen, the inoculation practice with Rhizobia is beneficial to the nitrogen nutrition of soybeans, especially in Rhizobium poor soils.

It was interesting that, during the growth season up to the flowering stage, $(\mathrm{N})$ plants accumulated higher nitrogen content than $(\mathrm{N}+\mathrm{R})$ plants, but the opposite was found true at initial pod filling stage, at which $(\mathrm{N}+$ $\mathrm{R})$ plants surpassed (N) plants in their nitrogen content (Fig. 2). 'This probably was ascribed to the consumption of a considerable amount of energy by $(\mathrm{N}+\mathrm{R})$ plants for nodulation process, which seemed to be in expense of the energy required for nitrate assimilation by the plants. The absence of promotion in nitrogen accumulation of shaded $(\mathrm{N}+\mathrm{R})$ plants at pod filling stage (Fig. 2) was attributed to the relatively low nitrogen accumulation in pods as compared to $\mathrm{N}$ - plants (Fig. 1 and Table 3 ).

Respecting the shading effect, data illustrated in Figs. 1 \& 2 reveal that, shaded plants accumulated low nitrogen content as compared to unshaded ones, and this was generally true with each of treatments. However, at initial pod filling stage, shaded $(\mathrm{N}+\mathrm{R})$ plants accumulated equal or higher amounts of nitrogen as compared to unshaded R-plants. This suggests the significance of combined nitrogen application for nodulated soybeans grown under shaded conditions.

Regarding the nitrogen accumulation in nodules, although the combined nitrogen proved to be promotive on the nitrogen accumulation in leaves, stems and roots, the opposite was found to be true concerning the nodules under both shaded and unshaded conditions (Fig. 1). This seemed to be mainly due to the depressive effect of combined nitrogen on nodulation ${ }^{9)}$.

Root respiration in relation to nitrogen accumulation

The relationship between respiratory activity of root system and nitrogen accumulation in soybean plant is shown in Table 2. Presented data reveal that, under both shaded and unshaded conditions, the higher the respiratory activity of root system the higher was the nitrogen accumulation in the plants. The calculated correlation coefficient $(r=0.952)$ indicates that the correlation between the two associated variables was highly significant. Data also show that, the unshaded plants proved to have a higher respiratory activity for root system than shaded ones, and this was true for each of the nitrogen source treatments.

The above findings indicate a) The significance of the possession of an active respiratory system by roots and/or nodules for an active uptake and/or fixation of nitrogen

Table 2. Relationship between respiratory activity of root system and nitrogen accumulated by soybean plant at initial flowering stage.

\begin{tabular}{|c|c|c|c|c|c|c|}
\hline \multirow{2}{*}{ Treatments } & \multicolumn{3}{|c|}{ Unshaded plants } & \multicolumn{3}{|c|}{ Shaded plants } \\
\hline & $\overline{\mathrm{N}}$ & $\mathrm{R}$ & $(\mathrm{N}+\mathrm{R})$ & $\mathrm{N}$ & $\mathrm{R}$ & $(\mathrm{N}+\mathrm{R})$ \\
\hline $\begin{array}{l}\text { N content } \\
(\mathrm{mg} / \text { plant })\end{array}$ & 125.0 & 80.0 & 105.0 & 100.0 & 45.0 & 72.5 \\
\hline $\begin{array}{l}\text { Respiratory activity } \\
\left(\mu 1 \mathrm{CO}_{2} \text { produced } / \text { plant } / \mathrm{hr}\right)\end{array}$ & 1033 & 500 & 867 & 750 & 417 & 550 \\
\hline
\end{tabular}

$r=0.952$ (L.S.C. at $1 \%$ level $=0.917$ ).

$\mathrm{N}$, combined nitrogen; R, Rhizobia ; $\mathrm{N}+\mathrm{R})$, combined nitrogen and Rhizobia. 
Table 3. Efficiency of pod productiona) of shaded and unshaded soybean plant as treated with combined nitrogen, Rhizobia or combined nitrogen and Rhizobia.

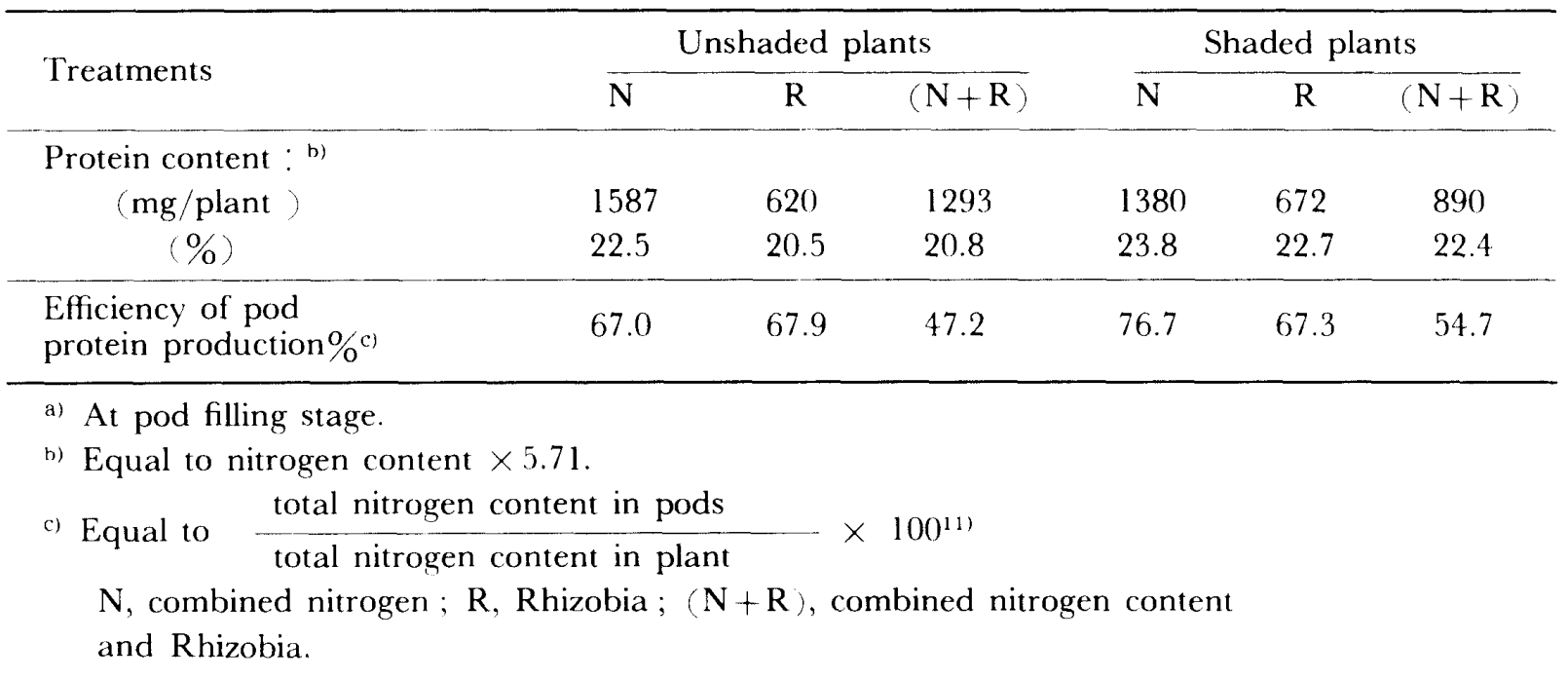

by soybeans and b) shading effect should be considered as an important factor controlling the nitrogen nutrition of soybean plant, particularly under combined cultivation in field, such as the combination between soybeans and maize.

Yield quality

The yield quality as indicated by the protein content and efficiency of pod protein production is shown in Table 3. Presented data reveal that under both shaded and unshaded conditions, $\mathrm{N}$-plants gave highest protein content in pods, and they were followed by $(\mathrm{N}+\mathrm{R})$ plants, whilst R-plants gave lowest protein content per plant in pods. At pod filling stage, the above results in combination with those illustrated in Fig. 2 indicate that, except for unshaded $(\mathrm{N}+\mathrm{R})$ plants, the higher the nitrogen accumulated in plant, the higher was the protein content per plant in pods, and this was true under both shaded and unshaded conditions. The exception concerning the unshaded $(\mathrm{N}+\mathrm{R})$ plants, showed the low efficiency of pod protein production of those plants (Table 3 ) which was, in turn, due to immaturity upon harvesting as compared to the other treatment plants, as visually observed.

Concerning the light intensity effect, pod protein percent was increased by shading for each of the treatments, though, the total protein content in pods per plant was decreased. Data in Table 3 also indicate that, shading increased the efficiency of pod protein production percent when the plants were treated with combined nitrogen, though, this increase could not reflect itself in the total protein content in pods.

The above results conclude the significance of combined nitrogen application for getting a high protein yield from soybean pods, especially in soils with low nitrogen content such as sandy soils.

\section{Summary}

A pot experiment was conducted in vermiculite with three treatments of soybeans namely a) plants grown with combined nitrogen without seed inoculation $(\mathrm{N}), \mathrm{b}$ ) plants were grown without combined nitrogen after seed inoculation with Rhizobia ( R) and c) plants grown with combined nitrogen after seed inoculation with Rhizobia $(\mathrm{N}+\mathrm{R})$. Treated plants were grown under $50 \%$ shade or under full sunlight. The experiment was carried out to investigate $i$ ) the seasonal variation in nitrogen accumulation for plants, ii) the relationship between root respiration and nitrogen accumulation in plant and iii) the efficiency of pod protein production under the different treatments. The following results were obtained.

1. R-plants accumulated lowest nitrogen content in their different parts whilst, at pod filling, $(\mathrm{N}+\mathrm{R})$ plants accumulated highest nitrogen content in their different plant parts except for pods and nodules.

2. Shaded plant generally accumulated 
low nitrogen content as compared to unshaded ones.

3. The correlation between the respiratory activity of root system and the nitrogen accumulation in plant was positive and highly significant

4. N-plants gave highest protein content in pods per plant and the opposite was found true concerning $\mathrm{R}$-plants. The efficiency of pod protein production of the plants fed with combined nitrogen was increased when they were shaded, though, this increase did not reflect itself in the total protein content in pods per plant.

The above results could conclude the significance of combined nitrogen application in addition to seed inoculation practice with Rhizobia for the nitrogen nutrition of noybeans particularly when they grow under shaded conditions such as combined cultivation, and in Rhizobia poor soils with low nitrogen content such as in sandy soils.

\section{Acknowledgement}

The author wishes to thank Prof. $\mathrm{K}$. KumazAWA and Dr. Y. ARIMA of the Laboratory of Plant Nutrition and Fertilizer, University of Tokyo, for their valuable advices and practical helps in this research.

\section{References}

1. Ailison. F.E., C.A. Lildwing, F.W. Minor and S.R. HoOver 1940. Biochemical nitrogen fixation studies: II. Comparative respiration of nodules and roots. Bot. Gaz. $101: 534-549$.

2. Association of Official Analytical Chemists 1975. "Official Methods of Analysis" Washington D.C. 20044. 12 th ed.

3. HASHIMOIO K. 1976. The significance of nitrogen nutrition to the seed yield and its related characters of soybeans. Res. Bull. Hokkaido Natl. Agric. Exp. Stn. Japan : 1--83.

4. Marsunaga, R., S. Matsimoto, I. Shimano and S. SHIMOI) 1983. Varietal differences in nitrogen response of soybeans associated with their nodulation. Japan. Jour. Crop Sci. 52: 423 $-429 *$
5. Minchin, F.R. and J.S. PATE 1973. The carbon balance of legume and functional economy of its root nodules. J. Exp. Bot. 24 : 259-271.

6. Norman, A.G. and I.O. Kramply 1954. The nitrogen nutrition of soybeans: II. Effect of available soil nitrogen. Soil Sci. Soc. Amer. Proc. 9: $191-196$

7. OHYAMA, T. and K. KLMAZAwa 1979. Assimilation and transport of nitrogenous compounds originated from ${ }^{15} \mathrm{~N}$ fixation and ${ }^{15} \mathrm{NO}_{3}$ absorption. Soil Sci. Plant. Nutr. $25: 9$ 19.

8. PAl, U.R. and M.S. SAXENA 1976. Relationship between nitrogen analysis of soybean tissues and soybean yield. Agron. J. 58 : 46-49.

9. RABIF, R.K. and K. KumazawA 1979. Effect of nitrate application and shade treatment on the nitrogen fixation and yield of soybean plant. Soil Sci. Plant Nutr. 25 : $467-476$.

10. Rabie, R.K., Y. ARIMA and K. KUMAZAWA 1980. Uptake and distribution of combined nitrogen and its incorporation into seeds of nodulated soybean plant as revealed by ${ }^{15} \mathrm{~N}$ studies. Soil Sci. Plant Nutr. 26 : $427-436$

11. TRANG, K.M. and J. GIID) Ns 1980. Shading and temperature as environmental factors affecting growth, nodulation, and symbiotic $\mathrm{N}_{2}$-fixation by sovbeans. Agron. J. 72 : 305-308.

12. TRL NG, B.C. and S. Yosmids 1983. Significance of nitrogen nutrition on the productivity of mungbean. Japan. Jour. Crop Sci. 52 : $493-499$.

13. WrHute, T.A.T. and D.A. Mil.t.r 1978. Effect of shading on $\mathrm{N}_{2}$-fixation, yield, and plant composition of field grown soybeans. Agron. J. $70: 387-392$.

14. WaIANabt, I., H. NAKANO and K. TABUChi 1983. Supplemental nitrogen fertilizer to soybeans: I. Effect of side dressing at early ripening stage on yield, yield components and protein content of seeds. Japan. Jour. Crop Sci. 52 : 291-298.*

15. Wrerbir, C.R. 1966. Nodulating and nonnodulating soybean isolines: II. Response to applied nitrogen and modified soil conditions. Agron. J. 58 : $46-49$.

16. Yoshind, T., 1.l.k and Y. YANG; 1977. Soil management and nitrogen fertilization for increasing soybean yield in Taiwan. SEFMIA Proc. Tokyo. 425-432

* In Japanese with English summary. 


\title{
〔和 文 摘 要 \\ ダイズにおける窯秦集㮴の季節的变化におよほす 化合態窒秦並ひに遮光の影䈏
}

\author{
Raafat K. RaBIE

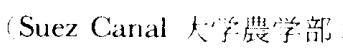

ダイズを用いて, 化合態窒素施用根粒菌無接種 $(\mathrm{N})$, 化合態窒素施用根粒菌接種 $(\mathrm{N}+\mathrm{R})$, 化合態窒

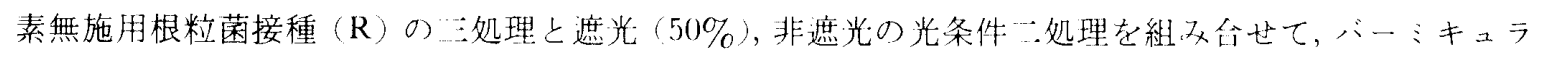
イトポット栽培法により, 植物体各部位の窒素集積の生育段階ごとの変化, 根采呼吸活性 $\left(\mathrm{CO}_{2}\right.$ 放出), 莢実蛋白生産効率（萊央 $\mathrm{N}$ 量／全植物体 $\mathrm{N}$ 量 $\times 100$ )を調バ，次のような結果を得た，

1. (R) 処理植物は，他の窒素源处理植物にくらへて植物体のいずれの部位についても最も低い梥 素含有量を示し；来た，萊帮肥大期では $(\mathrm{N}+\mathrm{R})$ 処理植物が莢実と根粒を除く各部位について最も高 い窒素含有量を示した。

2. 遮光処理植物は, 一般に非遮光植物にくらべて低い窒素含有量をふくした。

3. 根系の呼吸活性と植物体の窒素集積量との間には，有意の高い正の相関が認められた，

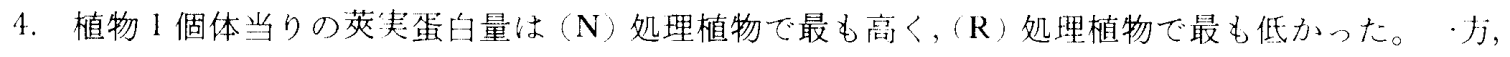

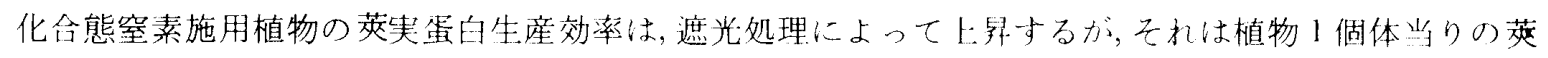
実総蛋白量の増加には反映しなかった。

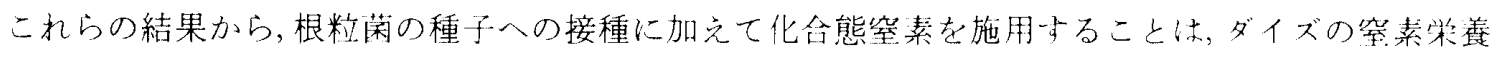
上有意義であり，上くに，間作のような遮光条件下や，砂質十壤の上うな窒素質に泛しく根䊉菌密度も 低い条件下での生育において有意義である上結論された。 